\title{
Protein Lin-54 Homolog
}

National Cancer Institute

\section{Source}

National Cancer Institute. Protein Lin-54 Homolog. NCI Thesaurus. Code C162422.

Protein lin-54 homolog (749 aa, $79 \mathrm{kDa}$ ) is encoded by the human LIN54 gene. This protein plays a role in DREAM complex-dependent cell cycle regulation. 